\title{
ANALISIS SITOGENETIK SEL EPITEL MUKOSA BUKAL PEKERJA STASIUN PENGISI BAHAN BAKAR UMUM DI KOTA YOGYAKARTA
}

\author{
CYTOGENETIC ANALYSIS IN THE BUCCAL CELLS \\ OF THE PETROL STATION WORKERS IN YOGYAKARTA CITY
}

\begin{abstract}
Regina TC. Tandelilin
Department of Oral Biology, Faculty of Dentistry, Universitas Gadjah Mada, Indonesia dan

Dental Hygiene Program, Faculty of Dentistry, Universitas Gadjah Mada, Indonesia
\end{abstract}

\author{
Elastria Widita \\ Dental Hygiene Program, Faculty of Dentistry, Universitas Gadjah Mada, Indonesia
}

\section{Rini Maya Puspita}

Department of Dental Biomedical, Faculty of Dentistry, Universitas Gadjah Mada, Indonesia

\author{
Tang Sze Mun \\ Klinik Pergigian Taman Medan, Selangor, Malaysia \\ Submitted:27-02-2019; Revised:14-02-2021; Accepted: 16-06-2021
}

\begin{abstract}
Workers employed in petroleum station have a high-risk exposure to a wide range of toxic compounds with known mutagenic and carcinogenic potential. Cytogenetic damage might have happened if they continuously exposed to petroleum derivatives. This study aimed to analyse the cytogenetic damage in exfoliated buccal cells among petroleum station workers in Yogyakarta City. This cross-sectional study was carried out on 30 petrol station workers who are working at a different petrol station in Yogyakarta and the control group consisted of 30 healthy subjects. Examination for all subjects included frequencies of nuclear abnormalities, including pycnosis, karyorrhexis, and karyolysis. Cytological preparations were stained according to papanicolaou reaction and analyzed under light microscope for making a score for degenerative nuclear alterations (pycnosis, karyolysis and karyorrhexis). Analysis of buccal cells revealed that frequencies of pycnosis and karyorrhexis in petrol station workers were significantly higher than the control group $(P<0.05)$. Conversely, there was no significant difference in karyolisis among groups. These findings indicate that the petrol station workers are under the risk of significant cytogenetic damage, particularly pycnosis and karyorrhexis.
\end{abstract}

Keywords: Buccal cells; Karyolysis; Karyorrhexis; Petrol station workers; and Pycnosis.

${ }^{*}$ Corresponding author: regina.tandelilin@ugm.ac.id

Copyright $\odot 2021$ THE AUTHOR(S).This article is distributed under a Creative Commons Attribution-Share Alike 4.0 International license. Jurnal Teknosains is published by the Graduate School of Universitas Gadjah Mada. 


\begin{abstract}
ABSTRAK
Pekerja stasiun pengisi bahan bakar umum (SPBU) merupakan pekerja yang secara kronis terpapar dengan derivat bensin. Kerusakan sitogenetik dapat terjadi akibat paparan berulang dan terus menerus. Tujuan penelitian ini adalah untuk mengkaji kerusakan sitotogenik pada sel epitel mukosa bukal pekerja SPBU di Yogyakarta. Penelitian potong lintang ini melibatkan 60 orang responden yang terbagi menjadi kelompok pekerja SPBU (30 subyek) serta kelompok kontrol (30 subyek). Sel epitel dari mukosa bukal diambil dengan individual cytobrush kemudian dilanjutkan proses histologi dengan menggunakan teknik pewarnaan papaniculaou. Frekuensi piknosis, karioreksis, dan kariolisis sebagai biomarker kerusakan sitogenetik dianalisis dan dibandingkan antara pekerja SPBU dan kelompok kontrol menggunakan t-test, $P<0.05$. Hasil analisis menunjukkan bahwa frekuensi sel epitel bukal yang mengalami piknosis dan karriorheksis pada kelompok pekerja SPBU lebih tinggi secara signifikan dibandingkan dengan kelompok kontrol $(P<0.05)$. Tidak terdapat perbedaan frekuensi sel yang mengalami kariolisis antara kedua kelompok. Pekerja SPBU memiliki risiko atas peningkatan sel yang mengalami piknosis dan kariorheksis dibandingkan kelompok bukan pekerja.
\end{abstract}

Kata Kunci: Karioreksis; Kariolisis; Piknosis; Pekerja SPBU; Sel epitel mukosa bukal.

\section{PENGANTAR}

Bensin merupakan campuran kompleks yang terdiri dari komponen molekuler dengan berat kecil, terdiri dari komposisi utama yaitu parafin, nafta, olefin dan komponen aromatik yang dapat mengakibatkan mutasi dan kanker. Komponen aromatik dari bensin terdiri dari benzene, toluena, dan xilena. Benzene dan derivatnya telah diklasifikasikan oleh International Agency for Research on Cancer (IARC) dan American Conference of Governmental Industrial Hygienist (ACGIH) sebagai senyawa yang bersifat karsinogenik terhadap manusia (Keretetse dkk., 2008 dan Baan dkk., 2009). Jutaan manusia di seluruh dunia memiliki risiko terpapar oleh benzene yang disebabkan oleh risiko dari pekerjaan maupun faktor lingkungan (Steinmaus dan Smith, 2017). Paparan yang terus menerus terhadap benzene dapat mengakibatkan homeotoksisitas, genotoksisitas, serta efek karsinogenik (Keretetse dkk., 2008 dan Baan dkk., 2009). Paparan kronis dapat menimbulkan efek yang lebih membahayakan pada kesehatan antara lain peningkatan adanya penyimpangan kromosom yang mengarah pada kanker, dampak terhadap fungsi reproduktif, bahkan kematian (Brosselin dkk., 2009, Paul dkk., 2016, dan Edokpolo dkk., 2015).

Pekerja stasiun pengisi bahan bakar umum (SPBU) merupakan pekerja yang secara kronis terpapar dengan bensin dan turunannya. Kajian epidemiologis yang telah dilakukan hingga saat ini menunjukkan adanya peningkatan bukti bahwa paparan dari benzene yang diterima oleh para pekerja berkaitan erat dengan sejumlah penyakit (Tunsaringkarn dkk., 2012, Edokpolo dkk., 2015, dan Paul dkk., 2016). Paparan kronis tersebut mayoritas terhirup melalui fraksi volatil dari bensin ketika melakukan pengisian bahan bakar (Martins dkk., 2009, Tunsaringkarn dkk., 2012, dan Paul dkk., 2016). Peningkatan risiko kejadian kanker pada pekerja pengisi bahan bakar telah dilaporkan (Chaiklieng dkk., 2019). Penelitian genetik juga telah membuktikan adanya peningkatan kerusakan sitogenetik pada limfosit darah tepi para pekerja yang terpapar pada bensin dan derivatnya (Keretetse dkk., 2008).

Beberapa penelitian telah melaporkan adanya efek pada kromosom pekerja yang terpapar benzene (Paul dkk., 2016, Moro dkk., 2012, Martins dkk., 2009, dan Rocha dkk., 2014). Inti sel atau nucleus yang abnormal (NA) adalah penanda biologis yang dapat digunakan untuk pengamatan pada seseorang atau suatu populasi yang terpapar karena dugaan peristiwa mutagenik, genotoksik, atau teratogenik. Metode uji mikronukleus serta kajian terhadap abnormalitas nukleus telah dikenal sebagai biomarker yang dapat diandalkan untuk mengkaji kerusakan kromosom. Kajian terdahulu menyatakan bahwa kerusakan kromosom dapat dideteksi dengan spesifitas yang tinggi melalui analisis penyimpangan degeneratif pada nukleus yang mengindikasikan kematian sel yaitu piknosis, 
kariolisis, dan karriorheksis (Tolbert dkk., 1992). Sebelumnya dilaporkan pula oleh Tolbert dan Cols (1991), bahwa selain diferensiasi seluler fisiologis, NA juga mengalami diferensiasi dan didapatkan teramati dalam proses kematian sel disertai dengan kerusakan DNA (Tolbert dkk., 1991). Nukleus dapat terdegradasi menjadi kromatin yang padat, inti terfragmentasi (kariorrhexis), inti pirnotik, atau bahkan kehilangan bahan intinya secara menyeluruh (karyolysis). Seperti telah diketahui bahwa beberapa sel jarang dapat dihambat dalam tahap pembentukan binukleus (dua nukleus) atau mungkin justru menunjukkan gambaran berupa tunas inti, yang kemudian disebutkan sebagai suatu biomarker untuk amplifikasi suatu gena (Holland dkk., 2008) Pengkajian abnormalitas nukleus pada sel mukosa bukal merupakan teknik non-invasif pada uji sitogenetik yang dipergunakan untuk mengkaji paparan terhadap suatu partikel toksik yang disebabkan oleh aktifitas pekerjaan.

Rongga mulut adalah tempat pertama masuknya berbagai macam bahan berbahaya ke dalam tubuh dan afeksinya dapat pula menunjukkan pada kondisi sistemik. Rongga mulut dapat disebut yang suatu keadaan yang mencerminkan kesehatan tubuh seseorang karena pada mukosa mulut inilah sering kejadian menunjukkan perubahan adanya suatu kelainan atau penyakit. Rongga mulut diketahui memiliki lapisan lembab yang berhubungan dengan bagian luar mulut yang dikenal sebagai mukosa mulut. Fungsi utama mukosa mulut terutama adalah untuk melindungi jaringan yang berada lebih dalam pada rongga mulut (Motgi dkk., 2014). Hal ini berfungsi sebagai penghalang atau pintu gerbang pertama terhadap potensi bahan berbahaya misalnya mikroorganisme pathogen maupun bahan yang berupa karsinogen.

Sel epitel mukosa bukal berperan penting menjadi penghalang pertama yang memadai untuk memetabolisme karsinogen terdekat menjadi produk reaktif (Motgi dkk., 2014). Mukosa bukal mulut disebutkan sebagai tampilan kesehatan individu, karena kerentanannya terhadap bahaya oleh bahan berbahaya sebelum mencerminkan kondisi sistemik kondisi (Torres-Bugarín dkk., 2014) Sel epitel rongga mulut merupakan target utama yang dapat diamati untuk menganalisi kejadian awal genotoksik yang diinduksi oleh agen karsinogenik melalui proses inhalasi atau penelanan (Moro dkk., 2012). Pengamatan biologis terhadap paparan senyawa kimia berbahaya pada lingkungan kerja merupakan prosedur yang penting untuk dilakukan dalam mengevaluasi risiko kesehatan manusia dan meningkatkan keamanan bekerja. Penelitian ini bertujuan untuk melakukan analisis sitogenetik dengan mengamati kerusakan sel berupa piknosis, kariolisis, dan karioreksis pada sel epitel mukosa bukal pada pekerja SPBU di Yogyakarta.

\section{Metode \\ Desain, subjek dan lokasi penelitian}

Penelitian ini merupakan penelitian potong lintang di wilayah Kota Yogyakarta dengan melibatkan 60 orang responden. Responden terbagi menjadi dua kelompok dengan jumlah yang sama pada masing-masing kelompok (kelompok kontrol; kelompok pekerja SPBU). Responden yang dilibatkan tidak mengkonsumsi alkohol dan obat-obatan, tidak sedang menderita lesi dalam rongga mulut serta tidak menderita penyakit sistemik (diabetes, jantung, dan kanker). Teknik purposive-random sampling digunakan dalam menentukan subjek penelitian. Responden yang diikutsertakan telah menyetujui seluruh prosedur penelitian dengan memberikan persetujuan secara tertulis berdasarkan pada prosedur yang telah disetujui oleh Komisi Etik Penelitian Fakultas Kedokteran Gigi UGM (No. 00722/KKEP/FKG-UGM/EC/2016).

\section{Pengambilan Sampel Sel Epitel Mukosa Bukal}

Epitel mukosa bukal diambil dengan metode usap menggunakan cytobrush pada setiap akhir shift bekerja. Subjek berkumur dengan akuades terlebih dahulu untuk selanjutnya dilakukan pengambilan sampel sel epitel mukosa bukal subjek menggunakan cytobrushyang telah dibasahi dengan $\mathrm{NaCl} 0,09 \%$ agar lembab (Rivera dan Núñez-de-Mendoza, 
2013). Cytobrush telah digunakan untuk mengakses sel-sel target pada mukosa bukal mulut para responden untuk pengumpulan atau koleksi sampel dalam studi ini . Alat maupun metode ini merupakan alat yang non-invasif, dengan biaya yang sangat sedikit, serta menghemat waktu untuk mengevaluasi terjadinya perubahan sitologi. Di samping itu, metode tersebut dapat dikatakan relatif mudah untuk menginterpretasikan hasilnya (Elesawy dkk., 2016). Setelah dilakukan usapan, sel yang telah menempel pada cytobrush diusapkan pada object glass dengan diputar berlawanan arah sekurangnya $360^{\circ}$. Selanjutnya dilakukan fiksasi dengan meneteskan cairan 95\% ethanol dan asam asetat glasial (3:1) pada object glass. Pengecatan dilakukan dengan teknik pewarnaan Papaniculaou.

Analisis sitogenetik dilakukan dengan mengkaji sel yang mengalami piknosis, karioreksis dan kariolisis (Tolbert dkk., 1992, dan Holland dkk., 2008). Kriteria penilaian sel yang mengalami piknosis adalah sel yang memiliki ukuran inti sel mengecil dan kromatin mengalami perubahan menjadi masa yang padat dan tidak berbentuk. Sel yang mengalami kariolisis diidentifikasi dengan area sitoplasmik yang merupakan ukuran dari sel terminal yang terdiferensiasi dengan disolusi nukleus gambaran ghost-like dari nukleus disertai adanya pembesaran dari basofil kromatin. Penilaian karioreksis dengan adanya sitoplasma intak dan posisi sel relatif datar, nukleus normal dan intak, perimeternya halus dan tampak berbeda (Tolbert dkk., 1992). Sel piknosis, karrioreksis dan kariolisis yang teridentifikasi dihitung per 1000 sel dengan menggunakan mikroskop cahaya perbesaran 1000x. Analisis sitogenetik pada sel epitel mukosa bukal dilakukan oleh dua orang dokter secara mandiri dengan blinded method.

\section{Analisis Data}

Data dianalisis menggunakan perangkat lunak statistik (SPSS 20). Semua data diuji normalitas dan homogenitas terlebih dahulu. Data hasil pengamatan inti sel piknosis, karioreksis, dan kariolisis ditampilkan menggunakan rerata \pm simpangan baku dan n (\%). Uji komparasi antar grup dilakukan menggunakan analisis T-test. Uji korelasi antar variabel dilakukan melalui uji Pearson. Nilai kepercayaan $P<0.05$ dianggap signifikan.

\section{HASIL DAN PEMBAHASAN}

Enampuluh responden yang terbagi menjadi dua kelompok (kelompok kontrol; pekerja SPBU) dengan proporsi yang sama (Tabel 1). Mayoritas responden berjenis kelamin laki-laki (60\%). Usia responden berada pada rentang 19-63 tahun dengan rerata 28,2 $\pm 10,1$. Rerata durasi paparan yang dimiliki oleh kelompok pekerja SPBU adalah 47,1 \pm $8,5 \mathrm{jam} /$ minggu. Mayoritas responden tidak memiliki kebiasaan merokok sebagaimana yang ditampilkan pada Tabel 1.

Tabel 1.

Karakteristik Responden

\begin{tabular}{l|l|l|l|l}
\hline \multicolumn{1}{c|}{ Variabel } & \multicolumn{1}{c}{ n } & \multicolumn{1}{c}{ Minimum } & Maksimum & Rerata + s.b. \\
\hline Usia (tahun) & 60 & 19 & 63 & $28,2 \pm 10,1$ \\
\hline Durasi bekerja (jam/minggu) & 30 & 32 & 56 & $47,1 \pm 8.5$ \\
\hline Jenis kelamin & 30 & & \\
\hline Perempuan & $\mathrm{n}(\%)$ & & \\
\hline Laki-laki & $24(40)$ & & \\
\hline Status Merokok & $36(60)$ & \\
\hline Tidak merokok & $\mathrm{n}(\%)$ & \\
\hline Merokok & $37(62)$ & \\
\hline
\end{tabular}

s.b. : simpangan baku

n (\%) : jumlah responden dan persentase per kelompok

*Grup pekerja SPBU 
Tabel 2 memperlihatkan bahwa analisis antara variabel dengan jumlah sel yang mengalami kerusakan sitogenik memperlihatkan bahwa tidak ada hubungan yang signifikan antara jenis kelamin, status merokok, serta usia $(P>0,05)$. Uji korelasi antara durasi bekerja dengan jumlah sel yang mengalami kerusakan sitogenetik memperlihatkan bahwa peningkatan lama bekerja berhubungan positif secara signifikan dengan piknosis dan karioreksis $(P<0,05)$.

Tabel 2.

Hubungan variabel dengan jumlah sel yang mengalami kerusakan sitogenetik

\begin{tabular}{|c|c|c|c|c|c|c|}
\hline Variabel & \multicolumn{2}{|c|}{ Piknosis } & \multicolumn{2}{|c|}{ Karioreksis } & \multicolumn{2}{|c|}{ Kariolisis } \\
\hline Jenis Kelamin & rerata \pm s.b. & $P \S$ & rerata \pm s.b. & $P \S$ & rerata \pm s.b. & $P \S$ \\
\hline Perempuan & $17,6 \pm 8,8$ & \multirow[t]{2}{*}{0,683} & $20,4 \pm 7,7$ & \multirow[t]{2}{*}{0,163} & $18,5 \pm 11,3$ & \multirow[t]{2}{*}{0,773} \\
\hline Laki-laki & $18,4 \pm 7,3$ & & $17,6 \pm 7,2$ & & $17,5 \pm 13,9$ & \\
\hline Status Merokok & rerata \pm s.b. & $P \S$ & rerata \pm s.b. & $P \S$ & rerata \pm s.b. & $P \S$ \\
\hline Tidak merokok & $18,5 \pm 8,9$ & \multirow[t]{2}{*}{0,587} & $19,7 \pm 6,9$ & \multirow[t]{2}{*}{0,202} & $16,1 \pm 11,9$ & \multirow[t]{2}{*}{0,158} \\
\hline \multirow[t]{2}{*}{ Merokok } & $17,4 \pm 6,0$ & & $17,2 \pm 8,2$ & & $20,9 \pm 14,1$ & \\
\hline & \multicolumn{6}{|l|}{$P \ddagger$} \\
\hline Usia (tahun) & \multicolumn{2}{|l|}{0,352} & \multicolumn{2}{|l|}{0,464} & \multicolumn{2}{|l|}{0,531} \\
\hline Durasi bekerja (jam/minggu) & \multicolumn{2}{|l|}{$<0,001$} & \multicolumn{2}{|l|}{0,015} & \multicolumn{2}{|l|}{0,853} \\
\hline
\end{tabular}

s.b. : simpangan baku

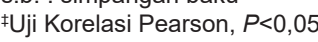

§Uji T-test, $P<0,05$

Hasil pengamatan melalui pengecatan Papanicolau (Gambar 1) menunjukkan adanya penyimpangan nukleus. Gambar 1 menunjuk- kan adanya sel dengan ukuran inti sel mengecil dan kromatin mengalami perubahan menjadi masa yang padat dan tidak berbentuk.
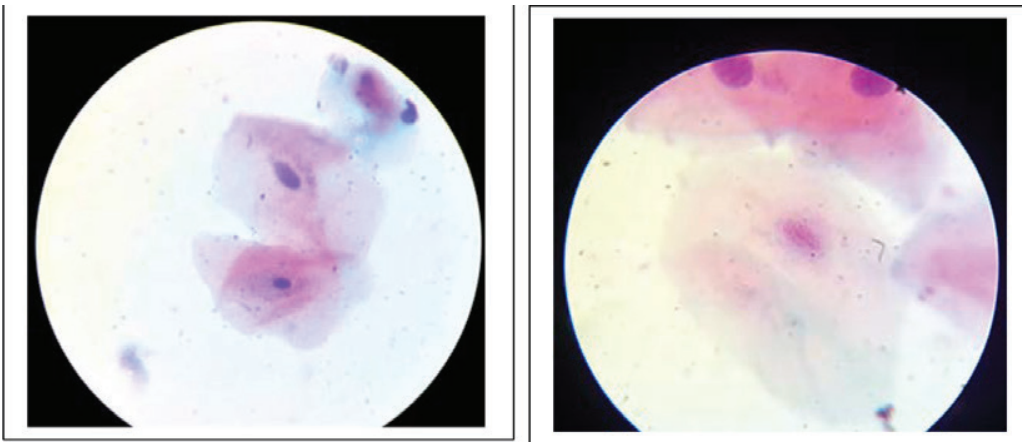

Gambar 1.

Inti sel yang mengalami mengalami piknosis, kariolisis dan

karioreksis pada pekerja SPBU (dari kiri ke kanan)

Teridentifikasi pula sel dengan area sitoplasmik yang merupakan ukuran dari sel terminal yang terdiferensiasi dengan disolusi nukleus gambaran ghost-like dari nukleus disertai adanya pembesaran dari basofil kromatin. Sel juga memperlihatkan area sitoplasma intak dan posisi sel relatif datar dengan perimeternya halus.

Perbandingan jumlah sel yang mengalami kerusakan sitogenetik dilakukan dengan
T-test (Tabel 3). Perbedaan secara signifikan ditunjukkan pada jumlah sel epitel bukal yang mengalami piknosis dan karriorheksis antara kelompok kontrol dan pekerja SPBU $(P<0.05)$, sedangkan jumlah sel yang mengalami kariolisis tidak menunjukkan perbedaan. Rerata frekwensi sel yang mengalami piknosis dan karriorheksis pada kelompok pekerja SPBU didapatkan lebih tinggi secara signifikan jika dibandingkan dengan kelompok kontrol. 

ANALISIS SITOGENETIK SEL EPITEL MUKOSA BUKAL PEKERJA STASIUN PENGISI ...

Tabel 3.

Perbandingan jumlah sel yang mengalami kerusakan sitogenetik antar kelompok

\begin{tabular}{l|l|l|l|l}
\hline \multicolumn{2}{c|}{ Variabel } & \multicolumn{1}{c|}{ Rerata \pm s.b. } & \multicolumn{1}{c}{ 95\% TK } & \multicolumn{1}{c}{$P$} \\
\hline \multirow{2}{*}{ Piknosis } & Kontrol $(\mathrm{n}=30)$ & $14,4 \pm 6,6$ & $11,9-16,8$ & \multirow{2}{*}{$<0,001$} \\
\cline { 2 - 5 } & Pekerja SPBU $(\mathrm{n}=30)$ & $21,8 \pm 7,3$ & $19,1-24,5$ & \\
\hline \multirow{2}{*}{ Karioreksis } & Kontrol $(\mathrm{n}=30)$ & $16,0 \pm 7,4$ & $13,3-18,8$ & \multirow{2}{*}{0,004} \\
\cline { 2 - 5 } & Pekerja SPBU $(\mathrm{n}=30)$ & $21,5 \pm 6,6$ & $19-23,9$ & \multirow{2}{*}{ Kariolisis } \\
\cline { 2 - 5 } & Kontrol $(\mathrm{n}=30)$ & $16,8 \pm 11,8$ & $12,4-21,1$ & \\
\cline { 2 - 5 } & Pekerja SPBU $(\mathrm{n}=30)$ & $19,1 \pm 14,0$ & $13,9-24,3$ & \\
\hline
\end{tabular}

s.b. : simpangan baku

TK : Tingkat kepercayaan

Uji independent $T$-test, $P<0,05$

Agen genotoksik dapat menyebabkan berbagai tipe kerusakan DNA yang mengarah pada perkembangan kanker (Edokpolo dkk., 2015). Kajian yang telah dilakukan menunjukkan bahwa para pekerja SPBU memiliki peningkatan risiko terhadap paparan dari bensin dan komponennya. Rerata frekuensi sel yang mengalami piknosis dan karriorheksis pada kelompok pekerja SPBU tampak lebih tinggi secara signifikan dibandingkan dengan kelompok kontrol.

Abnormalitas dari sel nukleus merupakan biomarker yang seringkali dipergunakan untuk mengamati paparan dari agen berbahaya pada individu yang dapat menyebabkan kejadian mutagenetik, genotoksik atau tetragenik. (Tolbert dkk., 1992, dan Holland dkk., 2008). Analisis yang dilakukan pada sel epitel mukosa bukal dapat memberikan gambaran abnormalitas dari nukleus yang jelas dan mudah dilakukan. Kariolisis dan karriorheksis merupakan indikator dari apoptosis (Kroemer dkk., 2005). Paparan berulang terhadap agen sitotoksik dapat mengakibatkan trauma kronis pada sel, proliferasi sel yang terkompensasi, hingga berakhir pada kanker (Metgud dkk., 2015). Berbagai macam faktor juga dapat mempengaruhi peningkatan kerusakan genotoksik seperti merokok, konsumsi alkohol, juga penggunaan obat kumur (Joshi dkk., 2011, Demirhan dan Tastemir, 2008, Lima dkk., 2010, dan Tucker dan Moore, 1996). Usia, jenis kelamin, dan merokok pada penelitian ini tidak memiliki keterkaitan secara signifikan pada kejadian kerusakan sitogenetik.
Tingginya frekuensi jumlah sel yang mengalami piknosis dan karriorheksis pada hasil penelitian ini dapat diduga disebabkan oleh efek genotoksik yang berasal dari paparan dari bensin dan derivatnya. Bensin memiliki sifat yang mudah menguap akibat adanya titik pembakaran yang rendah hingga di bawah suhu ruang dan berakibat terjadinya proses penguapan dan pembentukan uap. Rocha dkk. (2014) menyebutkan bahwa inhalasi dari uap bensin meski terjadi pada waktu yang singkat telah dilaporkan bersifat tidak aman. Paparan terhadap uap bensin sangat berbahaya pada manusia karena adanya komponen benzene yang dilaporkan sangat bersifat karsinogenik (Baan dkk., 2009). Benzene merupakan senyawa yang berfungsi untuk meningkatan efisiensi proses pembakaran. Paparan benzene secara akut dan kronis memiliki efek yang merusak dan mematikan (AlWakeel, 2017). Peningkatan jumlah sel yang mengalami piknosis dan karriorheksis mungkin disebabkan oleh komponen benzene (Keretetse dkk., 2008)

Pekerja SPBU merupakan pekerja yang secara kronis terapar oleh derivat bahan bakar ketika melakukan serangkaian proses pengisian bahan bakar. Paparan yang mungkin terjadi adalah melalui inhalasi, aspirasi dari fraksi volatil bahan bakar (Martins dkk., 2009, Tunsaringkarn dkk., 2012). Para pekerja tersebut bekerja mengisi ulang bahan bakar selama delapan jam dalam sehari. Sementara itu, peneliti sebelumnya menyebutkan bahwa paparan terhadap benzena meskipun dalam jumlah yang relatif kecil 
berpotensi karsinogenik. Dilaporkan bahwa penggunaan alat pelidung diri berupa masker berkaitan erat dengan penurunan paparan terhadap benzene pada para pekerja (Rocha dkk., 2014).

Sel bukal sebagai penghalang pertama untuk jalur inhalasi atau penelanan konsumsi makanan, akan mampu memetabolisme karsinogen terdekat menjadi produk reaktif (Holland dkk., 2008). Rongga area bukal mencakup ruang dan celah di bukal yang berdekatan dengan mulut dan meluas dari bibir ke orofaring. Mukosa mulut melapisi rongga bukal tersebut yang terdiri dari lapisan epitel berlapis-lapis yang meliputi membran basal, lamina propria dan lapisan jaringan ikat yang dipasok oleh pembuluh darah dan saraf (Dash dkk., 2013). Mengingat bahwa mukosa mulut sangat vaskularisatif, maka zat kimia yang diserap melalui mukosa mulut akan dapat langsung masuk ke sirkulasi sistemik, serta mampu melewati saluran pencernaan dan metabolisme pertama yang berlangsung di hepar (Zhang dkk., 2002). Penghirupan dapat menyebabkan rongga mulut terpapar bensin dan menunjukkan dampak buruk pada kondisi sel epitel mukosa bukal pula. Oleh karena itu, Holland et al. (2008) sebelumnya menjelaskan bahwa bahwa sel epitel rongga mulut dapat mewakili target sel untuk kejadian timbulnya genotoksik awal yang diinduksi oleh bahan karsinogenik yang memasuki tubuh melalui penghirupan dan penelanan makanan (Holland dkk., 2008).

Agen toksisitas dapat menginduksi reactive oxygen species (ROS) dalam jumlah yang besar sehingga dapat mengakitbatkan keracunan pada sel (Misra dkk., 2016). ROS merupakan faktor modulator yang sangat penting dalam sistim kekebalan tubuh, sistim saraf, infeksi, dan perkembangan kanker (Zhang, 2018). Rongga mulut merupakan pintu gerbang dari tubuh dengan kemungkinan yang tinggi atas paparan agen toksik pada rongga mulut melalui inhalasi dan penelanan. Agen tersebut dapat memicu terjadinya proses apoptosis pada basal sel dari mukosa bukal. Proses apoptosis yang tidak berfungsi akan mengakibatkan adanya pemusnahan yang berlebihan serta memperpanjang reaksi pertahanannya (Nikitakis dkk., 2004). Sel tersebut akan mengalami abnormalitas nukleus dengan terjadinya piknosis, karriorheksis, serta kariolisis.

Sel bukal merupakan kandidat jaringan pertama yang berfungsi untuk mengevaluasi efek sitotoksik. Hasil ini sesuai dan sejalan pula dengan laporan dari Torres dkk. (2014). Permeabilitas mukosa mulut di berbagai area mulut merupakan aspek penting untuk dapat dipertimbangkan saat menganalisis efek lokal bahan karsinogenik. Mukosa bukal merupakan jaringan tanpa keratin yang jauh lebih permeabel daripada jaringan berkeratin, seperti palatum dan gingiva (Elesawy dkk., 2016). Selain itu, mukosa mulut dilapisi oleh epitel berlapis yang terdiri dari beberapa lapisan sel yang menunjukkan berbagai tahap diferensiasi (maturasi) antara lapisan sel terdalam dan dengan lapisan pada permukaan. Mukosa bukal memiliki tingkat pergantian sel yang lebih tinggi, yaitu 25 hari (Berkovitz dkk., 2010, Palaskar dan Jindal, 2010, dan Squier dan Brogden, 2010). Laju pergantian lengkap pada sel epitel di daerah bukal ini cukup cepat, berkisar antara 5 sampai 6 hari, tetapi sel yang matang dan sel nonviable akan tetap pada bertahan lapisan permukaan (Borthakur dkk., 2008). Tingkat pergantian yang tinggi bersebut akan menginduksi pembaharuan sel secara berkelanjutan dengan memproduksi sel-sel oleh adanya mitosis di lapisan basal yang bermigrasi ke lapisan permukaan untuk menggantikan yang terkelupas untuk mempertahankan homeostasis epitel.

Laju proliferasi sel epitel bukal oral dapat dibatasi oleh beberapa keadaan misalnya kondisi dan perawatan sistemik (Torres-Bugarín dkk., 2014). Aktivitas mitosis dapat dipengaruhi oelh faktor-faktor seperti peradangan, waktu, dan stres. Cacat mitosis mengakibatkan berbagai kelainan inti, seperti mikronuklei, binukleasi, penampakan seperti telur pecah, inti pinotik dan kariorektik, serta peningkatan jumlah gambaran mitosis yang abnormal (Borthakur dkk., 2008). 
Dengan demikian daalam penelitian ini terjadi peningkatan kejadian kariorrhexis dan piknosis pada karyawan SPBU dibandingkan dengan kontrol. Selain itu, timbulnya transformasi kejadian malignansis dapat diduga disebabkan karena adanya faktor-faktor yang terganggunya keseimbangan laju penggantian sel dengan mitosis dan apoptosis (Bavle, 2014).

Adanya bukti kerusakan sitogenetik pada pekerja SPBU pada penelitian ini mengindikasikan bahwa perlu dilakukan peningkatan kewaspadaaan diri atas paparan dari agen toksik. Harapannya, kerusakan sitogenetik yang mengarah pada keadaan yang lebih parah seperti kanker dapat dicegah. Penelitian lanjutan perlu dilakukan untuk mengidentifikasi mekanisme yang jelas pada kerusakan sitogenetik yang dialami oleh pekerja SPBU. Informasi terkait dengan dosis paparan, gaya hidup, nutrisi, dan fungsi pertahanan tubuh juga diperlukan untuk memberikan gambaran yang jelas atas mekanisme hubungan yang dihasilkan terkait abnormalitas nukleus pada pekerja SPBU.

\section{SIMPULAN}

Efek paparan dari agen genotoksik yang terkait dengan risiko pekerjaan dapat dianalisis secara sitogenetik pada sel epitel mukosa bukal. Pekerja SPBU pada penelitian ini memiliki risiko yang tinggi terhadap kerusakan sitogenetik pada sel epitel mukosa bukal melalui peningkatan frekuensi piknosis dan karioreksis.

\section{UCAPAN TERIMA KASIH}

Ucapan terima kasih ditujukan kepada Fakultas Kedokteran Gigi UGM yang telah memberikan pendanaan serta berbagai pihak yang mendukung terselesaikannya penelitian ini.

\section{DAFTAR PUSTAKA}

Alwakeel, S. S. (2017). Microbiological and molecular identification of bacterial species isolated from nasal and oropharyngeal mucosa of fuel workers in Riyadh, Saudi Arabia. Saudi Journal of Biological Sciences, 24(6): 1281-1287.

Baan, R., Grosse, Y., Straif, K., Secretan, B., El Ghissassi, F., Bouvard, V., BenbrahimTallaa, L., Guha, N., Freeman, C., Galichet, L. dan Cogliano, V. (2009). A review of human carcinogens. Part F: Chemical agents and related occupations. The Lancet Oncology, 10(12): 1143-1144.

Bavle, R. M. (2014). Mitosis at a glance. Journal of Oral and Maxillofacial Pathology, 18(Suppl 1): S2-S5.

Berkovitz, B., Moxham, B., Linden, R. dan Sloan, A. (2010). Master Dentistry Volume 3 Oral Biology: Elsevier.

Borthakur, G., Butryee, C., StacewiczSapuntzakis, M. dan Bowen, P. E. (2008). Exfoliated Buccal Mucosa Cells as a Source of DNA to Study Oxidative Stress. Cancer Epidemiology Biomarkers \& Prevention, 17(1): 212219.

Brosselin, P., Rudant, J., Orsi, L., Leverger, G., Baruchel, A., Bertrand, Y., Nelken, B., Robert, A., Michel, G., Margueritte, G., Perel, Y., Mechinaud, F., Bordigoni, P., Hemon, D. dan Clavel, J. (2009). Acute childhood leukaemia and residence next to petrol stations and automotive repair garages: the ESCALE study (SFCE). Occupational and Environmental Medicine, 66(9): 598-606.

Chaiklieng, S., Suggaravetsiri, P. dan Autrup, H. (2019). Risk Assessment on Benzene Exposure among Gasoline Station Workers. International Journal of Environmental Research and Public Health, 16(14): 2545.

Dash, A., Singh, S. dan Tolman, J. (2013). Pharmaceutics: Basic Principles and Application to Pharmacy Practice: Elsevier.

Demirhan, O. dan Tastemir, D. (2008). Cytogenetic effects of ethanol on chronic alcohol users. Alcohol and Alcoholism, 43(2): 127-36. 
Edokpolo, B., Yu, Q. J. dan Connell, D. (2015). Health risk characterization for exposure to benzene in service stations and petroleum refineries environments using human adverse response data. Toxicol Rep, 2: 917-927.

Elesawy, B. H., Abd El Hafez, A., Shawky Mohamed, A. dan Mansour A. Salih, M. (2016). Application of Bethesda terminology to categorize buccal epithelial smears among petroleum station workers in Taif city, KSA. 2016, 5(3): 5.

Holland, N., Bolognesi, C., KirschVolders, M., Bonassi, S., Zeiger, E., Knasmueller, S. dan Fenech, M. (2008). The micronucleus assay in human buccal cells as a tool for biomonitoring DNA damage: the HUMN project perspective on current status and knowledge gaps. Mutation Research, 659(1-2): 93-108.

Joshi, M.S., Verma, Y., Gautam, A. K., Parmar, G., Lakkad, B. C. dan Kumar, S. (2011). Cytogenetic alterations in buccal mucosa cells of chewers of areca nut and tobacco. Arch Oral Biol, 56(1): 63-7.

Keretetse, G. S., Laubscher, P. J., Du Plessis, J. L., Pretorius, P. J., Van Der Westhuizen, F. H., Van Deventer, E., Van Dyk, E., Eloff, F. C., Van Aarde, M. N. dan Du Plessis, L. H. (2008). DNA damage and repair detected by the comet assay in lymphocytes of african petrol attendants: a pilot study. Annals of Occupational Hygiene, 52(7): 653-62.

Kroemer, G., El-Deiry, W. S., Golstein, P., Peter, M. E., Vaux, D., Vandenabeele, P., Zhivotovsky, B., Blagosklonny, M. V., Malorni, W., Knight, R. A., Piacentini, M., Nagata, S. dan Melino, G. (2005). Classification of cell death: recommendations of the Nomenclature Committee on Cell Death. Cell Death and Differentiation, 12 Suppl 2: 1463-7.
Lima, C. F., Oliveira, L. U., Cabral, L. A., Brandao, A. A., Salgado, M. A. dan Almeida, J. D. (2010). Cytogenetic damage of oral mucosa by consumption of alcohol, tobacco and illicit drugs. Journal of Oral Pathology and Medicine, 39(6): 441-6.

Martins, R. A., Gomes, G. A., Aguiar, O., Jr. dan Ribeiro, D. A. (2009). Biomonitoring of oral epithelial cells in petrol station attendants: comparison between buccal mucosa and lateral border of the tongue. Environment International, 35(7): 1062-5.

Metgud, R., Khajuria, N., Patel, S. dan Lerra, S. (2015). Nuclear anomalies in exfoliated buccal epithelial cells of petrol station attendants in Udaipur, Rajasthan. Journal of Cancer Research and Therapeutics, 11(4): 868-73.

Misra, A., Rai, S. dan Misra, D. (2016). Functional role of apoptosis in oral diseases: An update. Journal of oral and maxillofacial pathology : JOMFP, 20(3): 491-496.

Moro, A. M., Brucker, N., Charão, M., Bulcão, R., Freitas, F., Baierle, M., Nascimento, S., Valentini, J., Cassini, C., Salvador, M., Linden, R., Thiesen, F., Buffon, A., Moresco, R. dan Garcia, S. C. (2012). Evaluation of genotoxicity and oxidative damage in painters exposed to low levels of toluene. Mutation Research/ Genetic Toxicology and Environmental Mutagenesis, 746(1): 42-48.

Motgi, A., Chavan, M., Diwan, N., Chowdhery, A., Channe, P. dan Shete, M. (2014). Assessment of cytogenic damage in the form of micronuclei in oral epithelial cells in patients using smokeless and smoked form of tobacco and nontobacco users and its relevance for oral cancer. Journal of Cancer Research and Therapeutics, 10(1): 165-170. 
Nikitakis, N. G., Sauk, J. J. dan Papanicolaou, S. I. (2004). The role of apoptosis in oral disease: Mechanisms; aberrations in neoplastic, autoimmune, infectious, hematologic, and developmental diseases; and therapeutic opportunities. Oral Surgery, Oral Medicine, Oral Pathology, Oral Radiology, and Endodontology, 97(4): 476-490.

Palaskar, S. dan Jindal, C. (2010). Evaluation Of Micronuclei Using Papanicolaou And May Grunwald Giemsa Stain In Individuals With Different Tobacco Habits - A Comparative Study. Journal of Clinical and Diagnostic Research, 4(6): 3607-3613.

Paul, S., Chakraborty, A., Deb, B. dan Roy, P. (2016). Nuclear abnormalities in exfoliated buccal epithelial cells of petrol pump attendants of Southern Assam, India. Journal of Global Biosciences, 5(1): 3491-3499.

Rivera, C. dan Núñez-De-Mendoza, C. (2013). Exfoliative cytology of oral epithelial cells from patients with type 2 diabetes: cytomorphometric analysis. International Journal of Clinical and Experimental Medicine, 6(8): 667-676.

Rocha, L. P., Cezar-Vaz, M. R., Almeida, M. C. V. D., Bonow, C. A., Silva, M. S. D. dan Costa, V. Z. D. (2014). Use of personal protective equipment by gas stations workers: a nursing contribution. Texto \& Contexto Enfermagem, 23: 193-202.

Squier, C. dan Brogden, K. (2010). Human Oral Mucosa: Development, Structure and Function: Wiley-Blackwell.

Steinmaus, C. dan Smith, M. T. (2017). Steinmaus and Smith Respond to "Proximity to Gasoline Stations and Childhood Leukemia". Am J Epidemiol, 185(1): 5-7.
Tolbert, P. E., Shy, C. M. dan Allen, J. W. (1991). Micronuclei and other nuclear anomalies in buccal smears: a field test in snuff users. Am J Epidemiol, 134(8): 840-50.

Tolbert, P. E., Shy, C. M. dan Allen, J. W. (1992). Micronuclei and other nuclear anomalies in buccal smears: methods development. Mutation Research/Environmental Mutagenesis and Related Subjects, 271(1): 69-77.

Torres-Bugarín, O., Zavala-Cerna, M. G., Nava, A., Flores-García, A. dan Ramos-Ibarra, M. L. (2014). Potential uses, limitations, and basic procedures of micronuclei and nuclear abnormalities in buccal cells. Disease Markers, 2014: 1-13.

Tucker, J. D. dan Moore, D. H., (1996). The importance of age and smoking in evaluating adverse cytogenetic effects of exposure to environmental agents. Environmental Health Perspectives, 104 Suppl 3: 489-92.

Tunsaringkarn, T., Prueksasit, T., Kitwattanavong, M., Siriwong, W., Sematong, S., Zapuang, K. dan Rungsiyothin, A. (2012). Cancer risk analysis of benzene, formaldehyde and acetaldehyde on gasoline station workers. Journal of Environmental Engineering and Ecological Science, 1(1): 1-6.

Zhang, L., Eastmond, D. A. dan Smith, M. T. (2002). The nature of chromosomal aberrations detected in humans exposed to benzene. Critical Reviews in Toxicology, 32(1): 1-42.

Zhang, Y. (2018). Cell toxicity mechanism and biomarker. Clinical and translational medicine, $7(1)$ : 34-34. 